\title{
NEUROD1 wt Allele
}

National Cancer Institute

\section{Source}

National Cancer Institute. NEUROD1 wt Allele. NCI Thesaurus. Code C98201.

Human NEUROD 1 wild-type allele is located in the vicinity of $2 q 32$ and is approximately 8 $\mathrm{kb}$ in length. This allele, which encodes neurogenic differentiation factor 1 protein, is involved in both DNA binding and transcriptional activation. Mutation of the gene is associated with both maturity-onset diabetes of the young type 6 and type 2 diabetes mellitus. 